\title{
Recovery of Platinum Group Metals from Spent Automotive Catalysts Using Lithium Salts and Hydrochloric Acid
}

\author{
Shunsuke Kuzuhara ${ }^{1}$, Mina Ota ${ }^{1,+}$ and Ryo Kasuya ${ }^{2, *}$ (D) \\ 1 National Institute of Technology, Sendai College, 48 Nodayama, Medeshima-Shiote, \\ Natori 981-1239, Miyagi, Japan; kuzuhara@sendai-nct.ac.jp (S.K.); ota.mina.p2@dc.tohoku.ac.jp (M.O.) \\ 2 Global Zero Emission Research Center, National Institute of Advanced Industrial Science and \\ Technology (AIST), 16-1 Onogawa, Tsukuba 305-8569, Ibaraki, Japan \\ * Correspondence: ryo-kasuya@aist.go.jp; Tel.: +81-52-736-7595 \\ + Present address: Department of Metallurgy, Graduate School of Engineering, Tohoku University, \\ 6-6-02 Aramaki Aza Aoba, Aoba-ku, Sendai 980-8579, Miyagi, Japan.
}

Citation: Kuzuhara, S.; Ota, M.; Kasuya, R. Recovery of Platinum Group Metals from Spent

Automotive Catalysts Using Lithium Salts and Hydrochloric Acid. Materials 2021, 14, 6843. https:// doi.org/10.3390/ma14226843

Academic Editor: Olga Rodríguez Largo

Received: 20 October 2021

Accepted: 10 November 2021

Published: 12 November 2021

Publisher's Note: MDPI stays neutral with regard to jurisdictional claims in published maps and institutional affiliations.

Copyright: (C) 2021 by the authors. Licensee MDPI, Basel, Switzerland. This article is an open access article distributed under the terms and conditions of the Creative Commons Attribution (CC BY) license (https:/ / creativecommons.org/licenses/by/ $4.0 /)$.

\begin{abstract}
The recovery of platinum group metals (PGMs) from waste materials involves dissolving the waste in an aqueous solution. However, since PGMs are precious metals, their dissolution requires strong oxidizing agents such as chlorine gas and aqua regia. In this study, we aimed to recover PGMs via the calcination of spent automotive catalysts (autocatalysts) with Li salts based on the concept of "spent autocatalyst + waste lithium-ion batteries" and leaching with only $\mathrm{HCl}$. The results suggest that, when $\mathrm{Li}_{2} \mathrm{CO}_{3}$ was used, the Pt content was fully leached, while $94.9 \%$ and $97.5 \%$ of $\mathrm{Rh}$ and $\mathrm{Pd}$, respectively, were leached using $\mathrm{HCl}$ addition. Even when $\mathrm{LiF}$, which is a decomposition product of the electrolytic solution $\left(\mathrm{LiPF}_{6}\right)$, was used as the Li salt model, the PGM leaching rate did not significantly change. In addition, we studied the immobilization of fluorine on cordierite $\left(2 \mathrm{MgO} \cdot 2 \mathrm{Al}_{2} \mathrm{O}_{3} \cdot 5 \mathrm{SiO}_{2}\right)$, which is a matrix component of autocatalysts. Through the calcination of $\mathrm{LiF}$ in the presence of cordierite, we found that cordierite thermally decomposed, and fluorine was immobilized as $\mathrm{MgF}_{2}$.
\end{abstract}

Keywords: leaching; PGMs; LIBs; recycling; fluorine immobilization

\section{Introduction}

Platinum group metals (PGMs), which include $\mathrm{Pt}, \mathrm{Pd}, \mathrm{Rh}, \mathrm{Ir}, \mathrm{Ru}$, and Os, are used in various fields, including catalysis. PGMs are commonly employed in catalysts for the treatment of automobile exhaust gases. In 2020, the gross demand recorded for PGMs was 228.0 tons of $\mathrm{Pt}, 311.3$ tons of $\mathrm{Pd}$, and 31.7 tons for Rh [1]. However, only 153.8, 191.6, and 18.9 tons of $\mathrm{Pt}, \mathrm{Pd}$, and $\mathrm{Rh}$, respectively, were produced from mines; thus, the demand was not completely met. According to reports [1,2], the demand for PGMs has been met through mining and recycling for more than a decade.

Since PGMs are rare and expensive elements, their recovery and recycling from waste materials, including automotive catalysts (autocatalysts), have received growing attention. The International Energy Association (IEA) provided a forecast for electric vehicles (EVs) and assessed the impact that the coronavirus disease (COVID-19) will have on this market [3]. In this context, the term EV refers to both battery electric vehicles (BEVs) and plugin hybrid electric vehicles (PHEVs). According to the Stated Policies Scenario (STEPS), which presumes that policies announced thus far will be realized, the number of EVs worldwide will increase from 8.1 million recorded in 2019 to 140 million by 2030 (an increase of $\sim 30 \%$ annually). A total of 7.2 million EVs, which were passenger light-duty vehicles (PLDVs), existed in 2019, and this figure is expected to reach 43 and 119 million by 2025 and 2030, respectively.

Even in the "bright" future predicted by the STEPS, EVs will only account for approximately $10 \%$ of the PLDVs. Automobiles that are not BEVs or fuel-cell vehicles are equipped 
with internal combustion engines (ICEs), and it is expected that ICE-equipped vehicles will still account for approximately $91 \%$ and $84 \%$ of the total automobile sales in 2030 and 2040, respectively [4]. Since LDVs have a life expectancy of $\sim 15$ years [5], it is expected that PGM recovery from used autocatalysts will continue in the future.

The recovery of PGMs from waste materials usually involves dissolving the waste in an aqueous solution, such as an acid solution. Subsequent mutual separation processes, such as solvent extraction, precipitation separation, or ion exchange, target the PGM ions present in solution. However, since PGMs are precious metals, they are sparingly soluble in protonic acids (e.g., hydrochloric acid $(\mathrm{HCl})$ ). Therefore, on an industrial scale, acids containing oxidizing agents such as chlorine gas and aqua regia (a mixture of $\mathrm{HCl}$ and nitric acid) are employed [6,7]. While these oxidizing agents have great potential to oxidize PGMs, they are highly toxic and corrosive.

Previously, to avoid the use and generation of toxic gases, we proposed a novel dissolution process for PGMs based on composite oxides [8-13]. This novel process enables the PGMs to be oxidized (ionized) through their calcination with alkali metal salts, thereby avoiding the requirement of highly toxic oxidizing agents in the dissolution process. $\mathrm{Li}$ salts are especially suitable for recovering PGMs from waste materials as they universally form composite oxides. It is also well known that sodium salts such as $\mathrm{NaHSO}_{4}$ and $\mathrm{Na}_{2} \mathrm{O}_{2}$ are used in alkali fusion for the formation of complex oxides. In contrast, our new process utilizes oxygen from air as an oxidizing agent. In addition, solvent extraction using $\mathrm{HCl}$ can be applied in the existing process.

Currently, lithium-ion batteries (LIBs) account for up to $71 \%$ of the demand for Li [14]; LIBs are widely used in EVs and in small electronic devices, such as smartphones and laptop computers. Furthermore, the widespread use of LIBs has resulted in increased demands for Li. In the STEPS scenario from the IEA, it is expected that the demand for Li in 2040 may be 13 times higher than that of 2020 [15].

Since the several hundred charge/discharge cycles of LIBs result in their deterioration over a number of years $[16,17]$, it is expected that they will be discarded at approximately the same rate as that of their production [18]. Currently, the recycling rate of used LIBs is less than $1 \%[15,19]$, with $95 \%$ of them reaching landfills [20]. This improper disposal of used LIBs leads to environmental deterioration and renders the proper disposal and recovery of LIBs a necessity [21-23]. In order to recover metals from LIBs, we applied a carbon reduction method, which utilizes carbon powder as a reducing agent. Through this dry process, we succeeded in separating and recovering $\mathrm{Li}$ and Co from an LIB cathode model $\left(\mathrm{LiCOO}_{2}\right)$ [24]. When targeting waste LIBs, heating is an appropriate, inexpensive treatment; however, in such situations, it is necessary to control the levels of $\mathrm{F}$ originating from the electrolytes (e.g., lithium hexafluorophosphate, LiPF 6 ) and the binders (e.g., polyvinylidene difluoride, $\mathrm{PVDF}$ ) of these batteries. For example, $\mathrm{LiPF}_{6}$ decomposes due to the moisture in air to produce lithium fluoride $(\mathrm{LiF})$ and toxic fluorine-containing gases (e.g., $\mathrm{PF}_{5}, \mathrm{POF}_{3}$, and HF) [25,26]. However, HF emission from PVDF was drastically suppressed by the addition of calcium salts $[27,28]$. It is, therefore, necessary to consider removing $\mathrm{F}$ from the recovered materials or to apply processes to these materials that tolerate the presence of $\mathrm{F}$.

Thus, we herein report the recovery of PGMs from spent autocatalysts based on the concept of "spent autocatalyst + waste LIB $\rightarrow$ resources". In addition, we examine the immobilization of $\mathrm{F}$ on cordierite $\left(2 \mathrm{MgO} \cdot 2 \mathrm{Al}_{2} \mathrm{O}_{3} \cdot 5 \mathrm{SiO}_{2}\right)$, which is a matrix component of autocatalysts, with the aim of realizing cleaner production.

\section{Materials and Methods}

Figure 1 shows the flowchart of the leaching process. Herein, PGM recovery experiments from spent autocatalysts were conducted using lithium carbonate $\left(\mathrm{Li}_{2} \mathrm{CO}_{3}\right)$ and lithium fluoride $(\mathrm{LiF})$ as $\mathrm{Li}$ sources. 


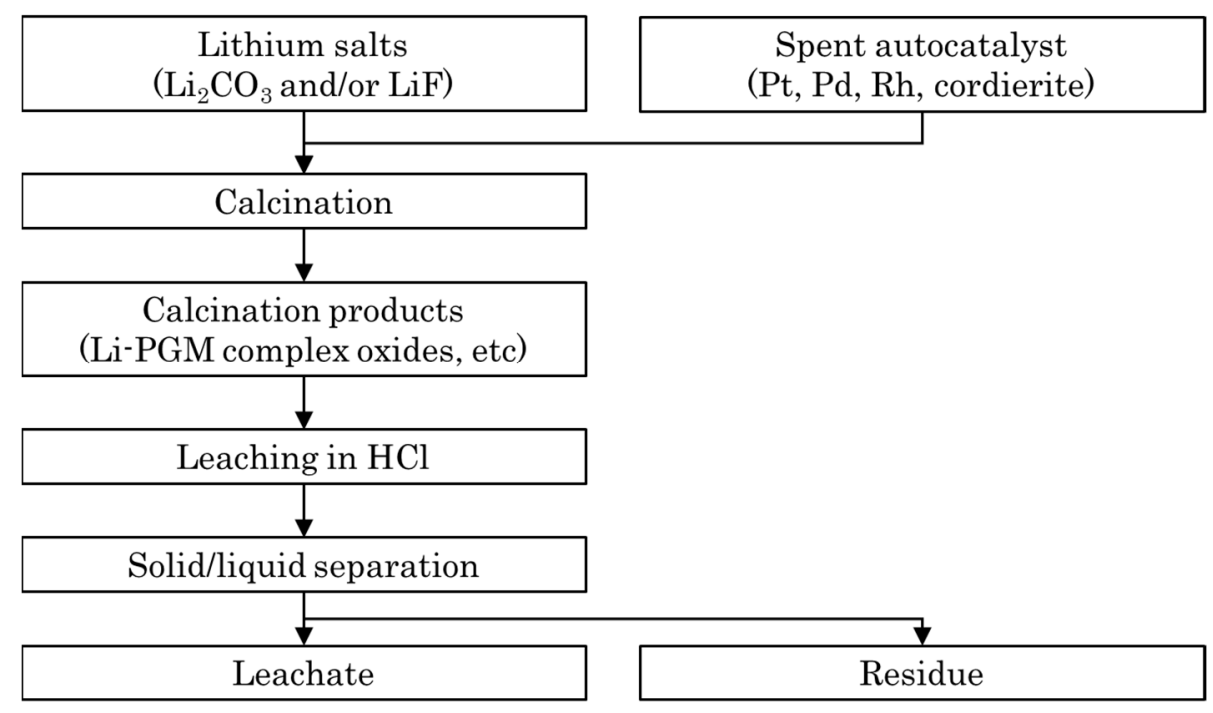

Figure 1. Flowchart of the platinum group metal (PGM) leaching process using Li salts.

\subsection{Sample Preparation}

\subsubsection{Starting Materials}

A spent autocatalyst (NIST, Standard Reference Materials 2557 Used Auto Catalyst (Monolith)), $\mathrm{Li}_{2} \mathrm{CO}_{3}$ (FUJIFILM Wako Pure Chemical Corporation, Osaka, Japan, Wako Special Grade 122-01132), LiF (FUJIFILM Wako Pure Chemical Corporation, Osaka, Japan, Wako Special Grade 127-01785), and synthetic cordierite $\left(2 \mathrm{MgO} \cdot 2 \mathrm{Al}_{2} \mathrm{O}_{3} \cdot 5 \mathrm{SiO}_{2}\right.$, Marusu Glaze Co., Ltd., Aichi, Japan, SS-200, mean particle size of $7.5 \mu \mathrm{m}$ ) were used. The spent autocatalyst comprised monolith catalysts collected from vehicles in the 1990s, which were then crushed and sieved through a 200 mesh $(<75 \mu \mathrm{m})$. Table 1 lists the concentrations of the various elements detected in the spent autocatalyst sample [29].

Table 1. Concentrations of elements present in the spent autocatalyst sample [29].

\begin{tabular}{cccc}
\hline Element & $\begin{array}{c}\text { Concentration } \\
(\mathbf{m g} / \mathbf{k g})\end{array}$ & Element & $\begin{array}{c}\text { Concentration } \\
\text { (mass\%) }\end{array}$ \\
\hline $\mathrm{Pt}$ & $1131 \pm 11$ & $\mathrm{Al}$ & 20 \\
$\mathrm{Pd}$ & $233.2 \pm 1.9$ & $\mathrm{Si}$ & 18 \\
$\mathrm{Rh}$ & $135.1 \pm 1.9$ & $\mathrm{Mg}$ & 6 \\
$\mathrm{~Pb}$ & $13,931 \pm 97$ & $\mathrm{Fe}$ & 1.5 \\
& & $\mathrm{Ce}$ & 1.3 \\
& & $\mathrm{Ni}$ & 0.5 \\
& & $\mathrm{Ba}$ & 0.29 \\
& & $\mathrm{Ca}$ & 0.2 \\
& $\mathrm{La}$ & 0.07 \\
\hline
\end{tabular}

\subsubsection{Sample Preparation}

Table 2 shows the conditions for sample preparation. Experimental samples were prepared by adding $\mathrm{Li}$ salts to synthetic cordierite or to the spent autocatalyst. $\mathrm{Li}_{2} \mathrm{CO}_{3}$ and $\mathrm{LiF}$ were employed as the Li salts.

After weighing the desired quantities of the aforementioned powders, the mixture was ground using an agate mortar and placed on an alumina boat (Sansyo Co., Ltd., Tokyo, Japan, SAB-995 AB-7). To prevent the Li salts from reacting with the alumina boat, a piece of gold foil was placed onto the boat, and the sample was then placed on top of it. 
Table 2. Quantities of reagents added and subsequent calcination conditions.

\begin{tabular}{|c|c|c|c|c|c|c|}
\hline \multirow{2}{*}{$\begin{array}{l}\text { Preparation } \\
\text { Conditions }\end{array}$} & \multicolumn{4}{|c|}{ Starting Materials } & \multirow{2}{*}{$\begin{array}{c}\text { Calcination } \\
\text { Temperature }\left({ }^{\circ} \mathrm{C}\right)\end{array}$} & \multirow[t]{2}{*}{ Holding Time (h) } \\
\hline & $\begin{array}{c}\text { Spent } \\
\text { Autocatalyst (g) }\end{array}$ & Cordierite (g) & $\mathrm{Li}_{2} \mathrm{CO}_{3}(\mathrm{mg})$ & $\mathrm{LiF}$ (mg) & & \\
\hline I-A & 1.0 & - & - & - & - & - \\
\hline I-B & 1.0 & - & - & - & 800 & 3 \\
\hline $\mathrm{I}-\mathrm{C}-\mathrm{1}^{1}$ & 1.0 & - & 100 & - & 800 & 3 \\
\hline $\mathrm{I}-\mathrm{C}-2$ & 1.0 & - & 75 & 25 & 800 & 3 \\
\hline $\mathrm{I}-\mathrm{C}-3$ & 1.0 & - & 50 & 50 & 800 & 3 \\
\hline I-C-4 & 1.0 & - & 25 & 75 & 800 & 3 \\
\hline $\mathrm{I}-\mathrm{C}-5$ & 1.0 & - & - & 100 & 800 & 3 \\
\hline I-D-1 & 1.0 & - & 100 & - & 600 & 3 \\
\hline I-D-2 & 1.0 & - & 100 & - & 700 & 3 \\
\hline I-D-3 ${ }^{1}$ & 1.0 & - & 100 & - & 800 & 3 \\
\hline I-D-4 & 1.0 & - & 100 & - & 900 & 3 \\
\hline I-E-1 & 1.0 & - & 100 & - & 800 & 0.5 \\
\hline I-E-2 & 1.0 & - & 100 & - & 800 & 1 \\
\hline I-E-3 & 1.0 & - & 100 & - & 800 & 2 \\
\hline I-E- $4^{1}$ & 1.0 & - & 100 & - & 800 & 3 \\
\hline II-A & - & 1.0 & - & - & 800 & 3 \\
\hline II-B & - & 1.0 & 500 & - & 800 & 3 \\
\hline II-C & - & 1.0 & - & 500 & 800 & 3 \\
\hline
\end{tabular}

${ }^{1}$ These sets of conditions were the same and gave the same sample.

\subsection{Calcination Experiments}

Figure 2 shows a schematic of the calcination apparatus employed in this study. A mixture of the starting materials was inserted into a quartz tube installed in an electric furnace (Koyo Thermo Systems Co., Ltd., Nara, Japan, KTF030N1). Both ends of the quartz tube were plugged with silicon caps, and air was passed from one end to the other at a rate of $100 \mathrm{~mL} / \mathrm{min}$. The temperature profile consisted of two steps; in the first step, the temperature was raised to $100{ }^{\circ} \mathrm{C}$ at a rate of $10{ }^{\circ} \mathrm{C} / \mathrm{min}$ and held at this temperature for $10 \mathrm{~min}$. In the second step, the temperature was raised to various other temperatures between 600 and $900{ }^{\circ} \mathrm{C}$. The sample was maintained at each temperature for $0.5-3 \mathrm{~h}$. Table 2 summarizes the calcination conditions. After calcination, the interior of the furnace was cooled to $<100{ }^{\circ} \mathrm{C}$ with a flow of air to obtain the calcined sample.

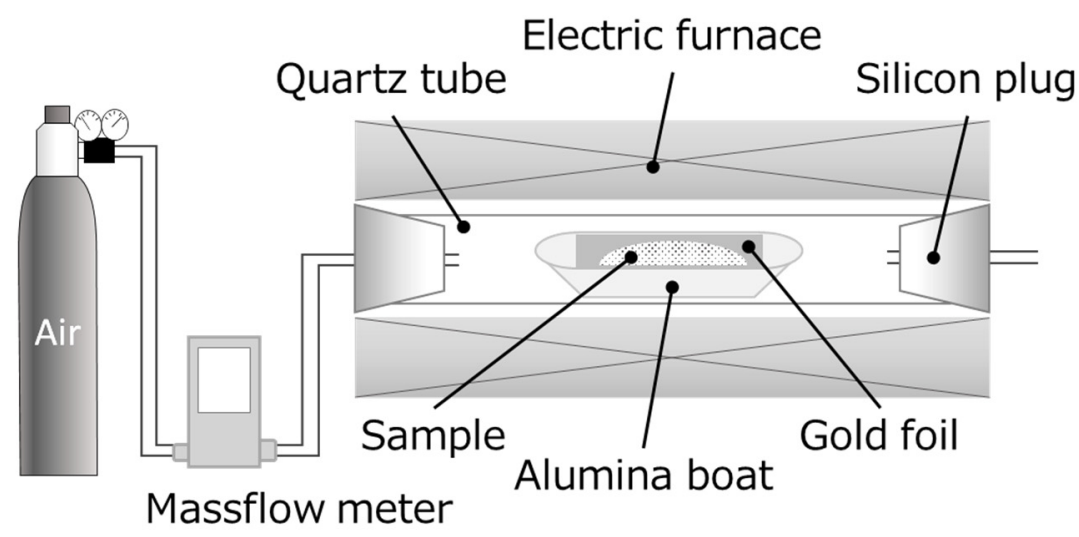

Figure 2. Schematic of the calcination apparatus.

\subsection{Leaching Experiments}

\subsubsection{Hydrochloric Acid}

The calcined sample was hand-crushed using an agate mortar, divided into two equal parts, and placed into two polytetrafluoroethylene (PTFE) inner-cylinder containers. A 
$12 \mathrm{M}(37 \%) \mathrm{HCl}$ solution (FUJIFILM Wako Pure Chemical Corporation, Osaka, Japan, Wako Grade $1087-01071$ ) was used to prepare $1.5 \mathrm{M}, 3 \mathrm{M}$, and $6 \mathrm{M} \mathrm{HCl}$ solutions by diluting with ultrapure water. To each container, a $\mathrm{HCl}$ solution of the desired concentration $(10 \mathrm{~mL})$ was added. These containers were then covered and placed in a pressure-resistant stainless-steel outer cylinder, which was then placed in an oven (ADVANTEC, DRN320DD). The oven temperature was raised to $40^{\circ} \mathrm{C}$ at a rate of $10^{\circ} \mathrm{C} / \mathrm{min}$, maintained for $5 \mathrm{~min}$, then further increased to $180^{\circ} \mathrm{C}$, and maintained at this temperature for $2 \mathrm{~h}$. Subsequently, the inside of the oven was cooled to $<100{ }^{\circ} \mathrm{C}$ under a flow of air prior to the removal of the reaction container. To suppress the reaction, the reaction container was rapidly cooled in a vat containing ice-water. The inside of the PTFE container was then washed with ultrapure water, and the solids were separated by filtering the reaction solution through a $0.2 \mu \mathrm{m}$ PTFE membrane filter under reduced pressure. The filtrate volume was made up to $100 \mathrm{~mL}$ with a $2.5 \% \mathrm{HCl}$ solution to provide the leachate. The solid residues were then leached using aqua regia (see Section 2.3.2).

\subsubsection{Aqua Regia}

A sample of the spent autocatalyst $(1.0 \mathrm{~g})$ and aqua regia $(30 \mathrm{~mL})$ were added to three tall beakers, and the beakers were heated on a hot plate at $150{ }^{\circ} \mathrm{C}$ for $1.5 \mathrm{~h}$. After cooling, the solids were separated by filtering the solutions through a PTFE membrane filter (pore size $=0.2 \mu \mathrm{m}$ ) under reduced pressure. The leachate was made by diluting the filtrate volume to $100 \mathrm{~mL}$ using a $2.5 \% \mathrm{HCl}$ solution. The solid residue was put into the beaker again to leach out the metals under the same leaching procedure. The leachate obtained after repeating this process five times was used for analysis.

\subsection{Characterization}

\subsubsection{Thermogravimetric-Differential Thermal Analysis}

Thermogravimetric-differential thermal analysis (TG-DTA) measurements of the samples were performed using a TG/DTA6300 instrument (Hitachi High-Tech Science Corporation, Tokyo, Japan). The desired sample $(10 \mathrm{mg})$ was charged to a $\varnothing 5 \mathrm{~mm}$ alumina cell and heated to $1000{ }^{\circ} \mathrm{C}$ at a rate of $10{ }^{\circ} \mathrm{C} / \mathrm{min}$ under a $300 \mathrm{~mL} / \mathrm{min}$ flow of air. As a reference sample, $\alpha-\mathrm{Al}_{2} \mathrm{O}_{3}$ powder was used.

\subsubsection{Elemental Analysis}

The concentrations of the metals $(\mathrm{Pt}, \mathrm{Rh}, \mathrm{Pd}$, and $\mathrm{Li})$ in the leachate were quantified using inductively coupled plasma mass spectrometry (ICP-MS, ELEMENT 2, Thermo Fisher Scientific, Waltham, MA, USA) or inductively coupled plasma atomic emission spectroscopy (ICP-AES, SPECTRO ARCOS, SPECTRO Analytical Instruments, Kleve, Germany). The amount of each leached metal was calculated using Equation (1). The quantities of the PGMs in the solid sample were calculated on the basis of the concentrations of the elements detected in the spent autocatalyst (see Table 1).

$$
\text { Leached metal amount }[\%]=\frac{\text { Quantity of metal in leachate }}{\text { Quantity of metal in solid sample }} \times 100 \text {. }
$$

\subsubsection{XRD Analysis}

The crystalline phase of the sample was identified by powder X-ray diffraction (XRD) analysis (Bruker Co., Ltd., Karlsruhe, Germany, D8 ADVANCE/L, USA). Measurements were taken at a voltage of $40 \mathrm{kV}$, a current of $40 \mathrm{~mA}$, and $2 \theta$ values of $10-80^{\circ}$ with a step width of $0.02^{\circ}$ and a counting time of $1 \mathrm{~s} / \mathrm{step}$.

\section{Results and Discussion}

\subsection{Calcination and Influence of $\mathrm{Li}_{2} \mathrm{CO}_{3}$ Addition}

Figure 3 shows the TG-DTA curves obtained for the spent autocatalyst alone and a mixture of the spent autocatalyst and $\mathrm{Li}_{2} \mathrm{CO}_{3}$. In Figure 3a, which shows the results 
obtained using the spent autocatalyst alone, an increase in weight was observed over two temperature regions: the initial temperature to $180{ }^{\circ} \mathrm{C}$ and $560{ }^{\circ} \mathrm{C}$ to $770{ }^{\circ} \mathrm{C}$. Although the weight decreased from $180{ }^{\circ} \mathrm{C}$ to $560{ }^{\circ} \mathrm{C}$ and above $770{ }^{\circ} \mathrm{C}$, in all situations, the maximum change in weight was approximately $\pm 0.2 \%$. A very subtle peak attributed to an endothermic reaction close to $777^{\circ} \mathrm{C}$ was also observed. In contrast, the weight of the sample containing $\mathrm{Li}_{2} \mathrm{CO}_{3}$ (Figure $3 \mathrm{~b}$ ) decreased by $5 \%$ between $545^{\circ} \mathrm{C}$ and $735^{\circ} \mathrm{C}$; the endothermic peak observed at $720^{\circ} \mathrm{C}$ was attributed to the melting of $\mathrm{Li}_{2} \mathrm{CO}_{3}$ (m.p. $\mathrm{Li}_{2} \mathrm{CO}_{3}=723^{\circ} \mathrm{C}$ ) [30]. The exothermal reaction due to the formation of complex oxides could not be observed because the small amount of PGMs precluded detection.

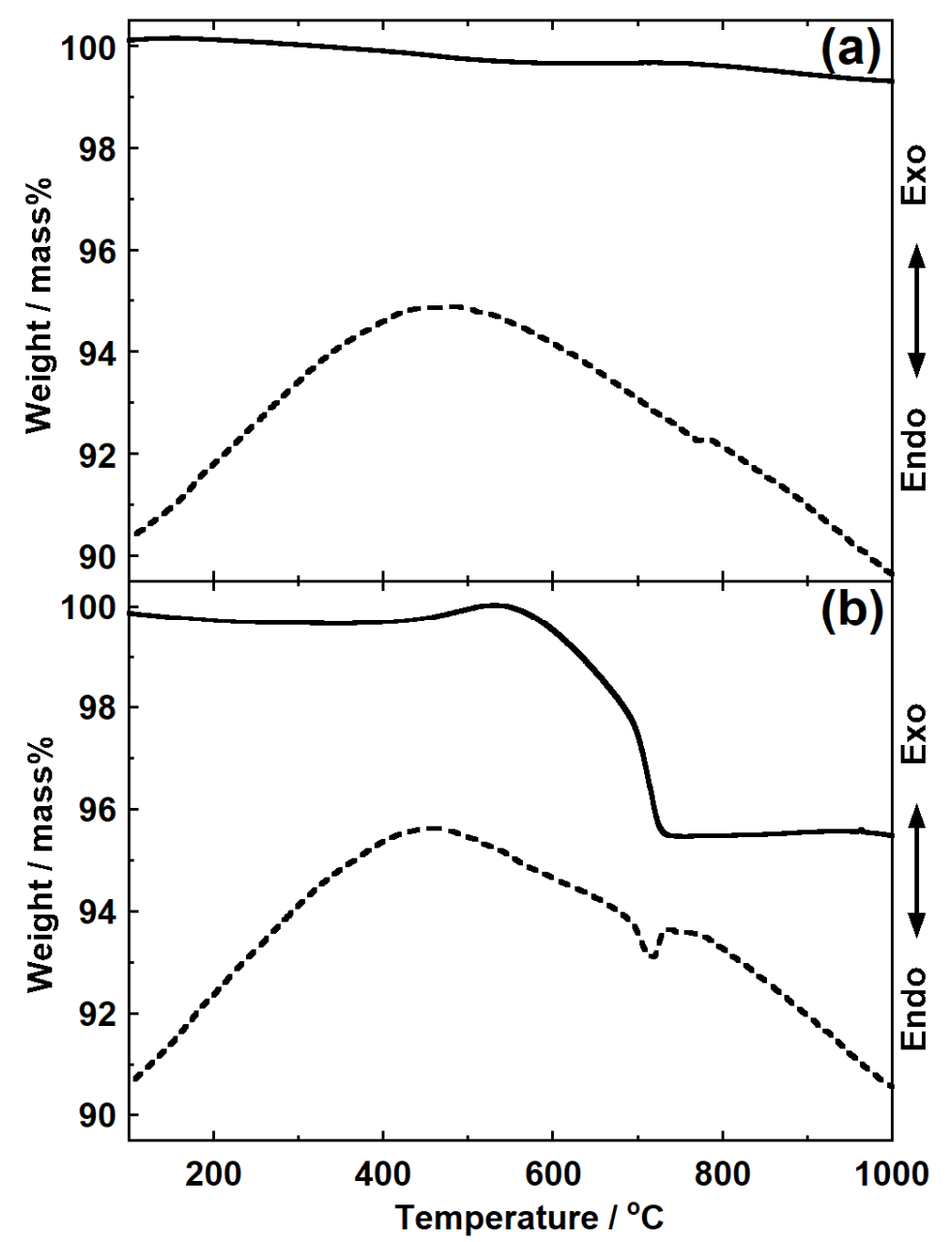

Figure 3. Thermogravimetric-differential thermal analysis (TG-DTA) profiles of samples obtained using (a) the spent autocatalyst alone and (b) the spent autocatalyst with $\mathrm{Li}_{2} \mathrm{CO}_{3}$. Solid lines: TG curves; dashed lines: DTA curves.

Figure $4 \mathrm{a}, \mathrm{b}$ show the XRD profiles obtained for the spent autocatalyst before calcination (condition I-A) and after calcination at $800{ }^{\circ} \mathrm{C}$ for $3 \mathrm{~h}$ (condition I-B). In both profiles, diffraction peaks corresponding to cordierite were observed. Furthermore, the enlarged image shown in Figure $4 \mathrm{c}$ indicates that the diffraction between $10^{\circ}$ and $11^{\circ}$ shifted toward a higher angle following calcination. As this peak originated from the 100 diffraction of cordierite, this observation indicates that calcination reduced the $a$-axis lattice constant. In addition, as shown in Figure $4 \mathrm{c}-\mathrm{e}$, new peaks were detected between $26.5^{\circ}$ and $27^{\circ}$, and between $34^{\circ}$ and $34.5^{\circ}$ after calcination. Despite their low peak intensities, these findings suggest the generation of trace amounts of new compounds. 

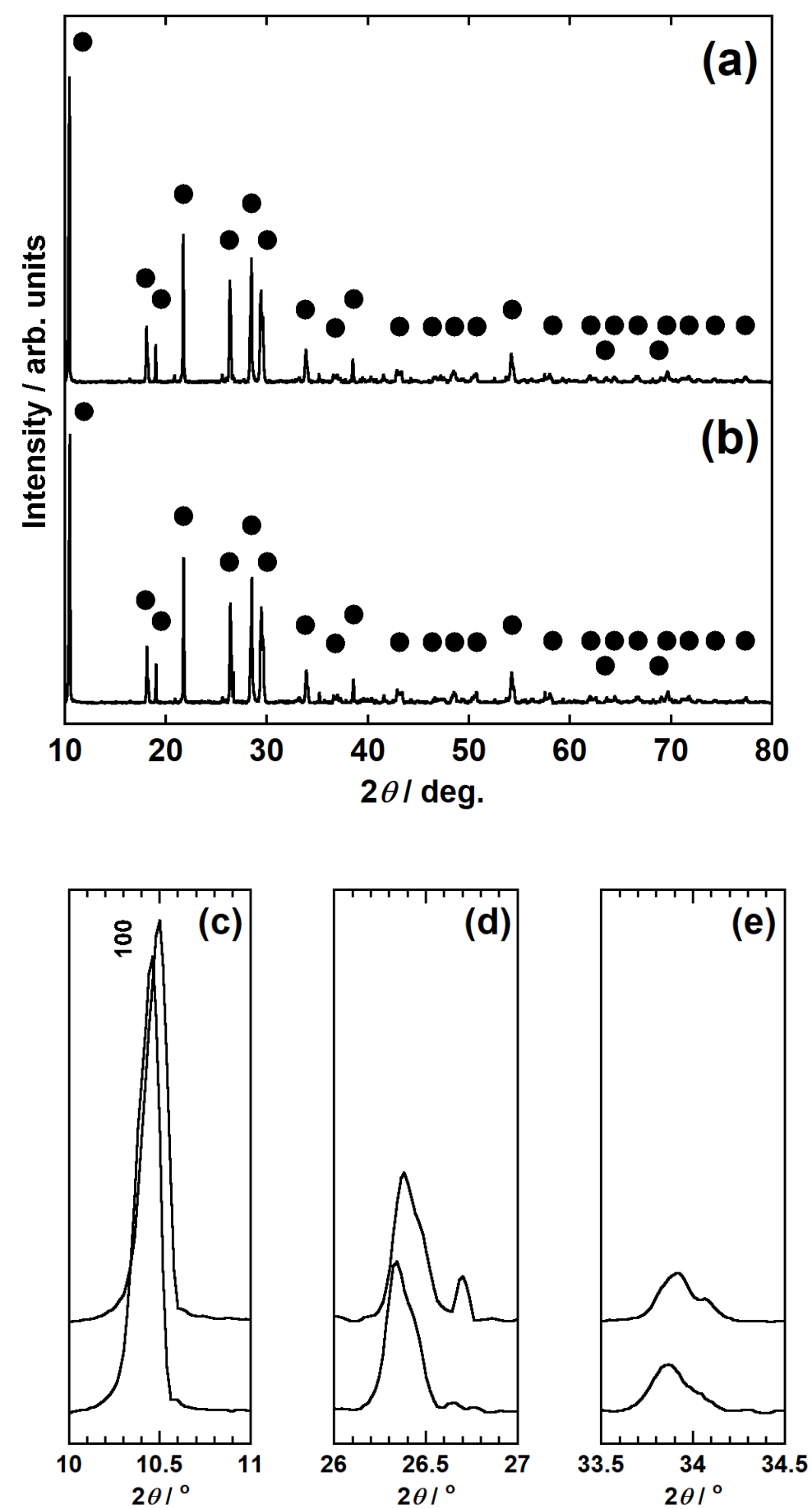

Figure 4. X-ray diffraction (XRD) profiles of the spent autocatalyst samples obtained (a) before calcination (condition I-A) and (b) after calcination at $800^{\circ} \mathrm{C}$ for $3 \mathrm{~h}$ (condition I-B). The black circles indicate the cordierite phase. (c-e) Enlarged XRD profiles of the spent autocatalyst samples. Lower plot: condition I-A; upper plot: condition I-B.

Figure 5 shows the results of PGM leaching by calcination and $\mathrm{Li}_{2} \mathrm{CO}_{3}$ addition. When an uncalcined sample (condition I-A) was leached using $\mathrm{HCl}$ alone, the amount of $\mathrm{Pt}$ leached was $4.5 \%$, which was significantly lower than that achieved using aqua regia (91.7\%). In contrast, the amount of Pt leached from a calcined sample at $800{ }^{\circ} \mathrm{C}$ for $3 \mathrm{~h}$ (condition I-B) increased to $84.3 \%$. Moreover, the combination of $\mathrm{Li}_{2} \mathrm{CO}_{3}$ addition and calcination (condition I-C-1) resulted in the complete leaching of Pt. 


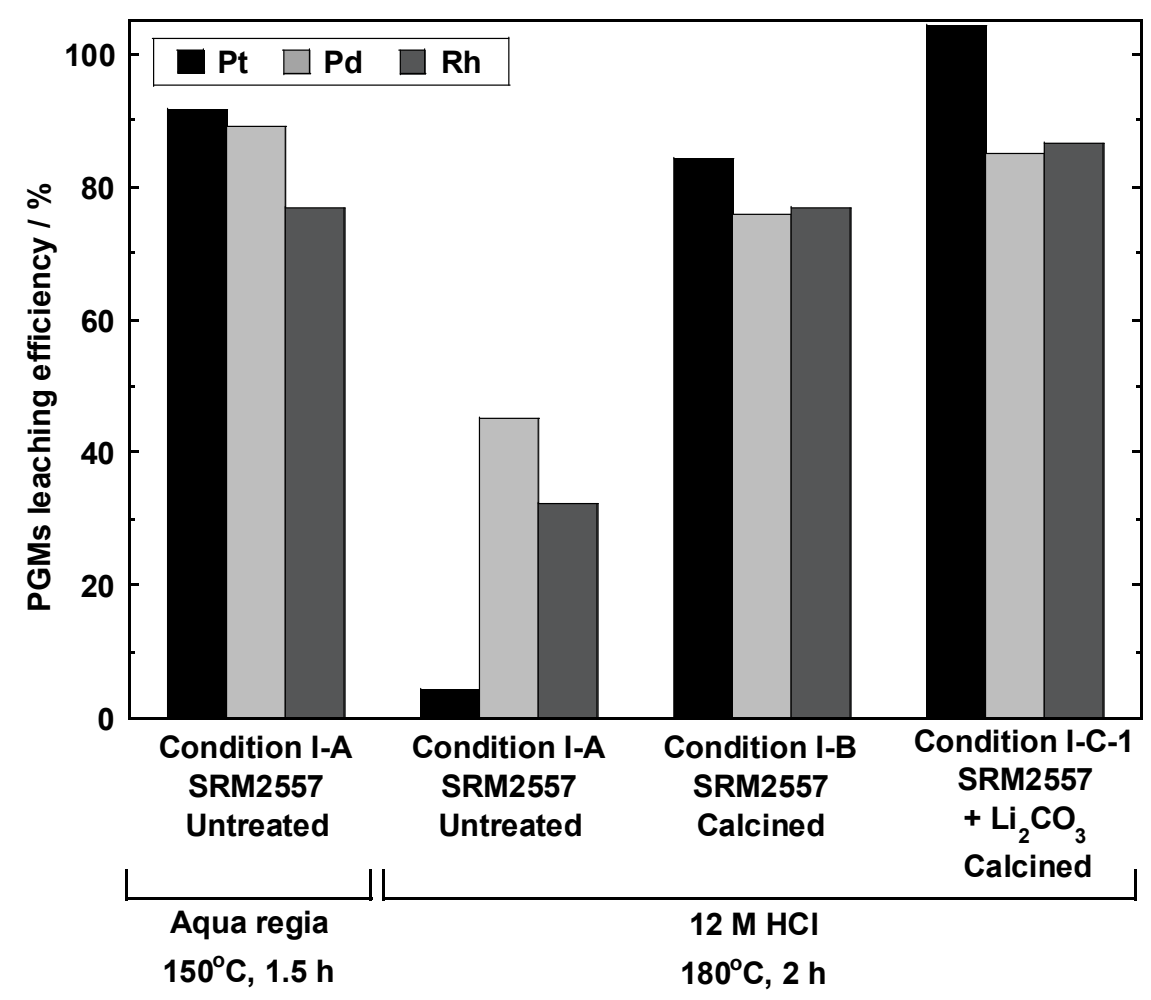

Figure 5. Pt, Pd, and Rh leaching efficiencies in the solutions obtained under conditions I-A, I-B, and I-C-1.

Similarly, the amounts of $\mathrm{Rh}$ and $\mathrm{Pd}$ leached into $\mathrm{HCl}$ under condition I-A were $28.3 \%$ and $42.0 \%$, respectively, which are less than half the quantities leached upon treatment with aqua regia. In contrast, the amounts of leached $\mathrm{Rh}$ and $\mathrm{Pd}$ under condition I-B increased to $76.9 \%$ and $75.9 \%$, respectively, and they increased further to $86.5 \%$ and $85.0 \%$, respectively, under condition I-C- 1 . These results revealed that the calcination with $\mathrm{Li}_{2} \mathrm{CO}_{3}$ effectively improved the $\mathrm{Pt}, \mathrm{Rh}$, and $\mathrm{Pd}$ leaching rates.

The increased amount of leached PGMs observed upon Li-salt addition was attributed to the generation of composite oxides that are soluble in $\mathrm{HCl}$. Moreover, the majority of PGMs were found to be leached using $\mathrm{HCl}$ alone when sample calcination was carried out in advance, even in the absence of Li salts. Although the reason for this remains unclear, it is assumed to be due to the impact of compounds that can oxidize PGMs, such as Ce-oxide co-catalysts present in the spent autocatalysts.

\subsection{Impact of $\mathrm{Li}_{2} \mathrm{CO}_{3}$ Concentration in Li Salt Mixture (Conditions I-C and II)}

Figure 6 shows the amount of PGMs leached upon varying the ratio between $\mathrm{Li}_{2} \mathrm{CO}_{3}$ and LiF additives (conditions I-C-1, I-C-2, I-C-3, I-C-4, and I-C-5). As indicated, complete Pt leaching was achieved under condition I-C-1 ( $\mathrm{Li}_{2} \mathrm{CO}_{3}$ concentration: 100 mass\%). Although the amount of leached Pt slightly decreased as the amount of added LiF increased, the former remained sufficiently high (95.3\%) even at a LiF concentration of $100 \mathrm{mass} \%$ (condition I-C-5). Because these values were all higher than those achieved when leaching was carried out using aqua regia, the effects of Li-salt addition were observed. In contrast, the maximum amounts of leached $\mathrm{Rh}$ and $\mathrm{Pd}$ were $86.5 \%$ and $86.1 \%$, respectively, and there was no clear correlation between these amounts and the concentration of $\mathrm{Li}_{2} \mathrm{CO}_{3}$ in the Li-salt mixture. As seen in Figure 5, the leaching rates of $\mathrm{Pt}$ and $\mathrm{Rh}$ increased when using Li salts and $\mathrm{HCl}$, while that of Pd remained unchanged. Moreover, a higher Pd leaching rate was achieved in aqua regia. 


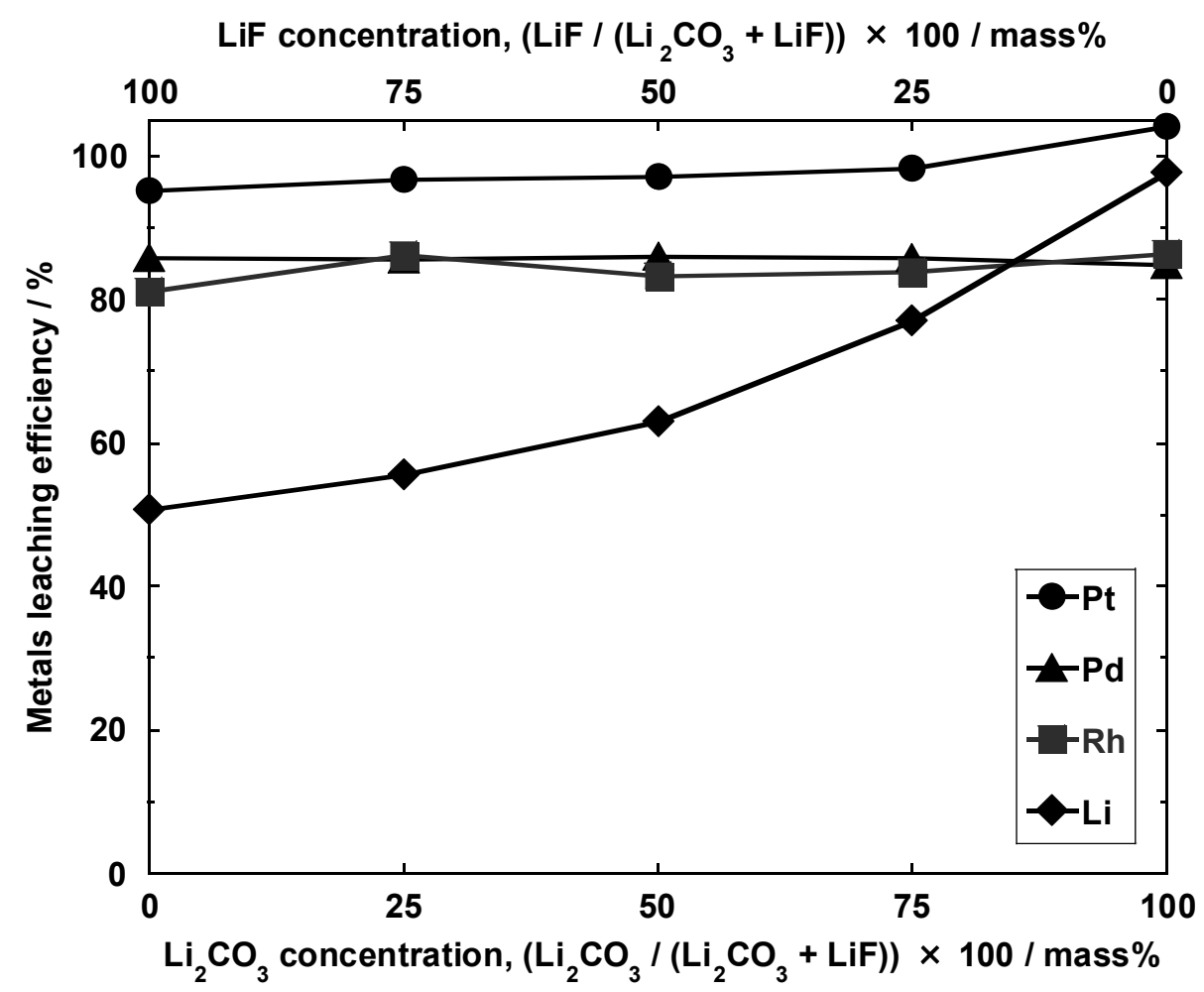

Figure 6. $\mathrm{Pt}, \mathrm{Pd}, \mathrm{Rh}$, and $\mathrm{Li}$ leaching efficiencies in the solution samples obtained under conditions I-C-1, I-C-2, I-C-3, I-C-4, and I-C-5. Dissolution conditions: $12 \mathrm{M} \mathrm{HCl}$ at $180{ }^{\circ} \mathrm{C}$ for $2 \mathrm{~h}$.

The amount of leached Li was the highest under condition I-C-1 (97.9\%) and tended to decrease as the ratio of $\mathrm{Li}_{2} \mathrm{CO}_{3} /\left(\mathrm{Li}_{2} \mathrm{CO}_{3}+\mathrm{LiF}\right)$ decreased. Indeed, under condition I-C-5 (100 mass \% LiF), this amount was reduced to $50.7 \%$. We could not detect Li even after the aqua regia treatment of the solid residues remaining after $\mathrm{HCl}$ leaching. On the basis of these observations, we envisaged that approximately half of the added Li was converted to a form that is insoluble even in aqua regia.

Figure 7 shows the XRD profiles of calcined samples containing cordierite (conditions II-A, II-B, and II-C), while Figure 8 shows those of the residues after $\mathrm{HCl}$ leaching. After calcination of cordierite alone (Condition II-A, Figure 7a), the crystal structure was maintained, while $\mathrm{MgAl}_{2} \mathrm{O}_{4}$ was the main phase after leaching (Figure 8a). This showed that $\mathrm{Si}$ was separated from cordierite and that its crystal phase changed. When $\mathrm{Li}_{2} \mathrm{CO}_{3}$ was added (condition II-B, Figure $7 \mathrm{~b}$ ), $\mathrm{Li}_{2} \mathrm{O}\left(\mathrm{Al}_{2} \mathrm{O}_{3}\right) \mathrm{SiO}_{2}, \mathrm{Li}_{4} \mathrm{SiO}_{4}$, and $\mathrm{MgAl}_{2} \mathrm{O}_{4}$ were generated after calcination. The diffraction peaks of these Li complex oxides disappeared after leaching, and only $\mathrm{MgAl}_{2} \mathrm{O}_{4}$ was detected in the crystalline phase (Figure $8 \mathrm{~b}$ ). Although they were not detectable through XRD analysis because of their low concentrations, $\mathrm{Pt}, \mathrm{Rh}$, and $\mathrm{Pd}$ produced complex oxides with $\mathrm{Li}$ that are soluble in $\mathrm{HCl}$, which in turn improved the leaching rates of the PGMs. Regardless of Li salt addition, the residues showed a wide range of diffraction peaks from $17^{\circ}$ to $27^{\circ}$. This suggests that amorphous components are present in the sample. According to the positions of the diffraction peaks, these may originate from an amorphous Si compound [31].

Even in the case of the sample where LiF was added (condition II-C, Figure 7c), cordierite decomposed during calcination to give $\mathrm{LiAlSiO}_{4}$ and $\mathrm{MgF}_{2}$. Although the rate of $\mathrm{Li}$ leaching by $\mathrm{HCl}$ decreased with the addition of $\mathrm{LiF}$ (Figure 6), this may have been due to the incorporation of $\mathrm{Li}$ into a compound that is sparingly soluble in $\mathrm{HCl}$, e.g., $\mathrm{MgF}_{2}$. In contrast, the PGM leaching rate did not significantly decrease even when the type of Li salt was changed. On the basis of the observations, it was inferred that the formation of PGM-containing complex oxides proceeded regardless of the type of Li salt employed. 


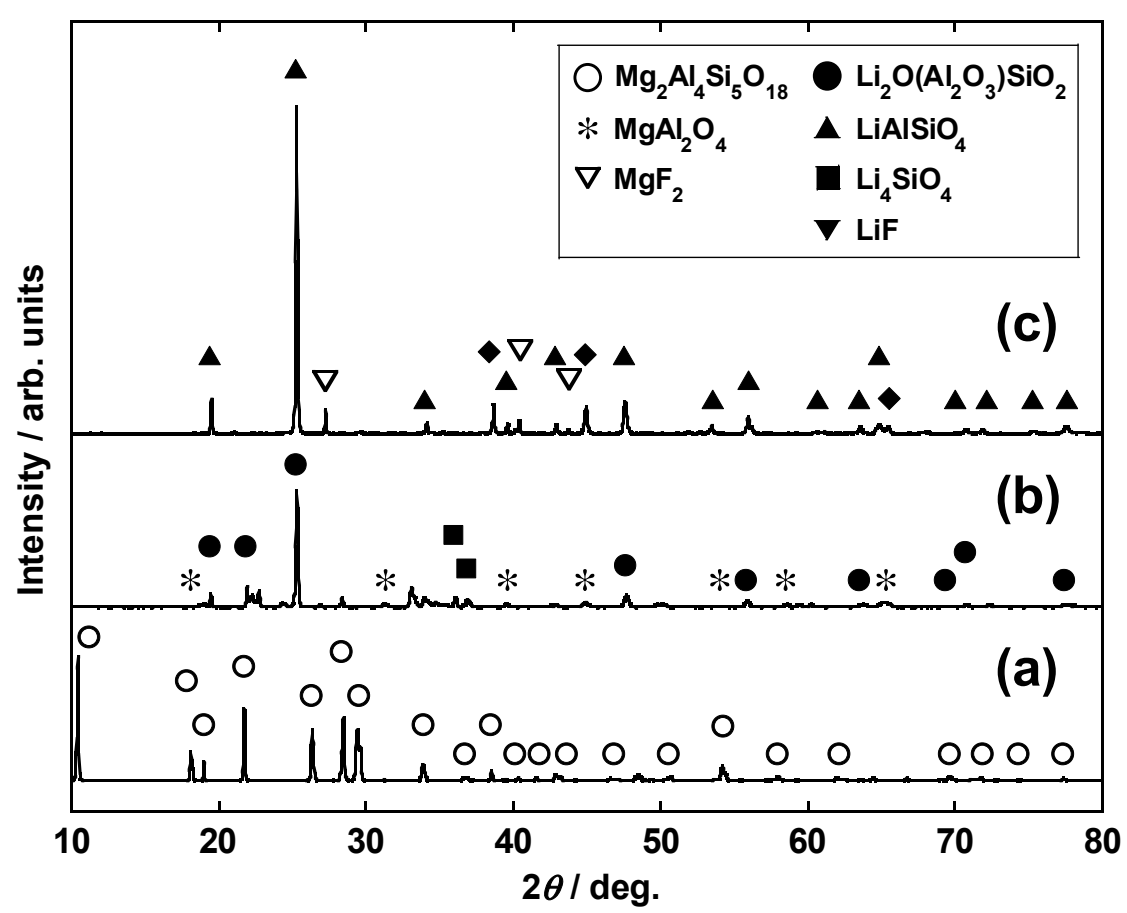

Figure 7. XRD profiles of the cordierite-containing calcined samples obtained under conditions (a) II-A, (b) II-B, and (c) II-C.

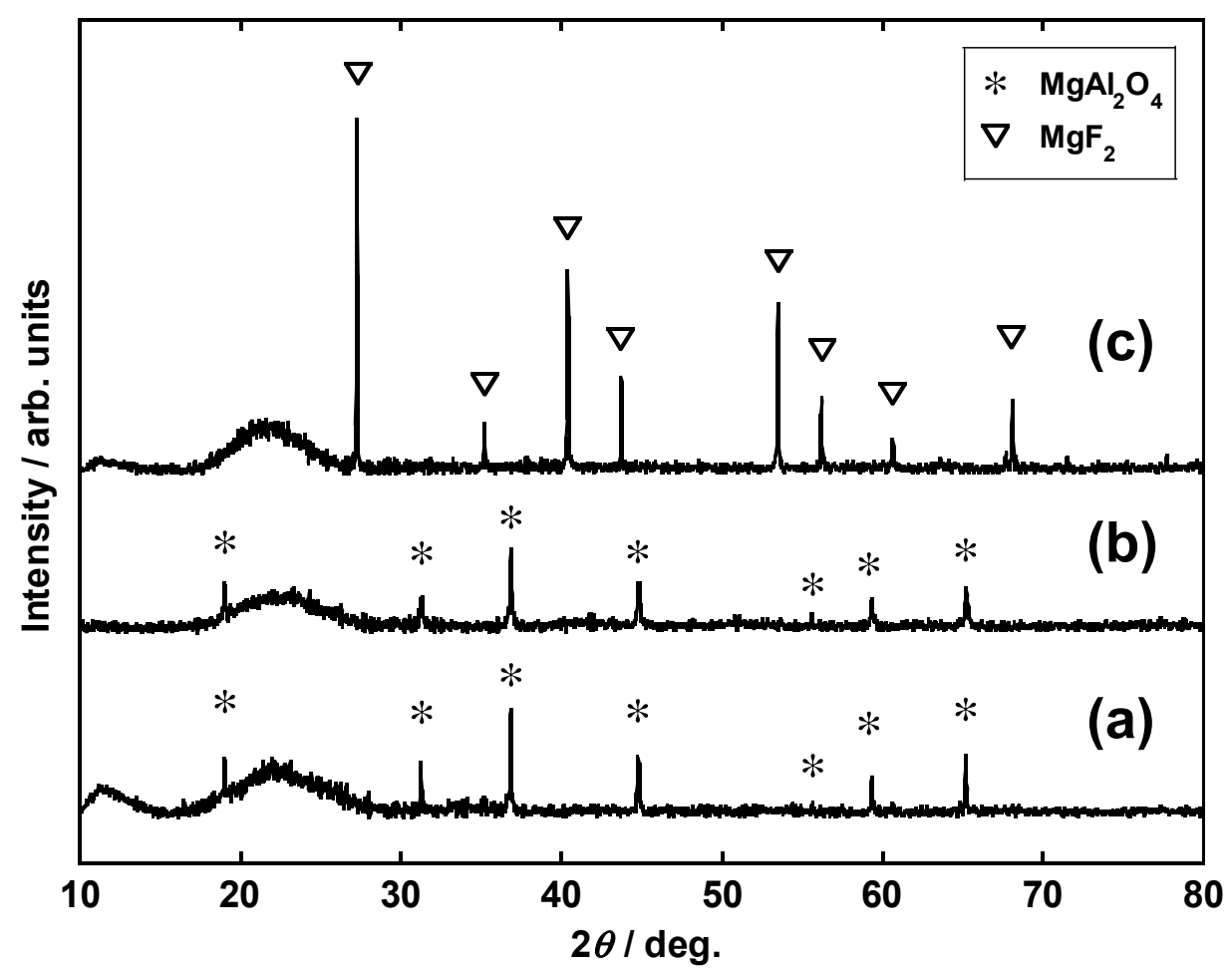

Figure 8. XRD profiles of the residues obtained under conditions (a) II-A, (b) II-B, and (c) II-C. Dissolution conditions: $12 \mathrm{M} \mathrm{HCl}$ at $180{ }^{\circ} \mathrm{C}$ for $2 \mathrm{~h}$.

\subsection{Effects of Various Parameters on PGM Leaching}

3.3.1. $\mathrm{HCl}$ Concentration and the Type of Li Salt (Conditions I-C-1 and I-C-5)

Figure 9 shows the relationship between the $\mathrm{HCl}$ concentration and the leaching rates of various metals. When the $\mathrm{HCl}$ concentration was increased to $1.5,3,6$, and $12 \mathrm{M}$, the leaching rates of $\mathrm{Pt}$ from the samples with added $\mathrm{Li}_{2} \mathrm{CO}_{3}$ (condition I-C-1) increased to 
$62.9 \%, 84.6 \%, 87.4 \%$, and $104.2 \%$, respectively. For the same increase in $\mathrm{HCl}$ concentration, the leaching rates of $\mathrm{Pt}$ from the samples with added $\mathrm{LiF}$ (condition I-C-5) increased to $78.7 \%, 83.1 \%, 83.0 \%$, and $95.3 \%$, respectively. Although the leaching rate of Pt increased with increasing $\mathrm{HCl}$ concentration, there was no significant difference in the leaching rate at $\mathrm{HCl}$ concentrations of 3 and $6 \mathrm{M}$. Furthermore, except at $1.5 \mathrm{M} \mathrm{HCl}$, the leaching rates increased with increasing $\mathrm{Li}_{2} \mathrm{CO}_{3} /\left(\mathrm{Li}_{2} \mathrm{CO}_{3}+\mathrm{LiF}\right)$ ratio. The leaching behavior of $\mathrm{Pd}$ was similar to that of Pt. The leaching rates of $\mathrm{Rh}$ increased remarkably with $\mathrm{HCl}$ concentration irrespective of the type of Li salt.
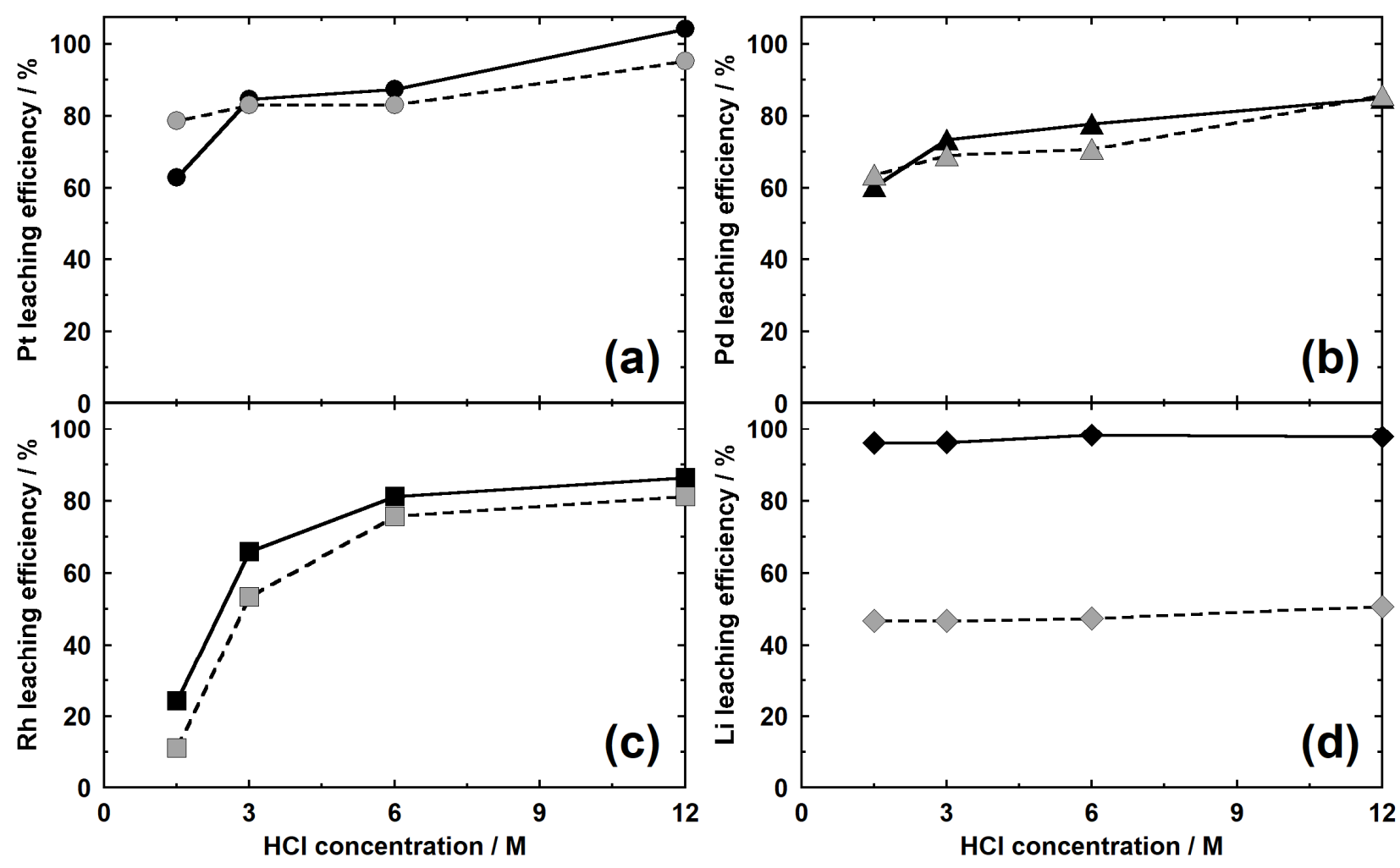

Figure 9. Metal leaching efficiencies of the samples obtained under conditions I-C-1 and I-C-5. (a) Pt, (b) Pd, (c) Rh, and (d) Li. Solid lines: condition I-C-1, dashed lines: condition I-C-5.

Through the calcination of the Li salt and the use of spent autocatalysts, the leaching rates of PGMs into $\mathrm{HCl}$ drastically increased compared to those of the untreated samples [12]. This is due to the generation of Li-PGM complex oxides that are soluble in $\mathrm{HCl}$. Under condition I-C-1, Pt, Pd, and Rh are considered to convert to $\mathrm{Li}_{2} \mathrm{PtO}_{3}, \mathrm{Li}_{2} \mathrm{PdO}_{2}$, and $\mathrm{LiRhO}_{2}$, respectively. As previously described, the leaching rate of $\mathrm{Pt}$ from $\mathrm{Li}_{2} \mathrm{PtO}_{3}$ increased with $\mathrm{HCl}$ concentration [9]. This is consistent with the results obtained in this study. Although $\mathrm{Li}_{2} \mathrm{PdO}_{2}$ easily dissolves in low-concentration $\mathrm{HCl}$ at ambient temperatures [11], under the conditions examined in our study, the complete leaching of Pd was not possible. This may have been due to the incorporation of $\mathrm{Pd}$ in the host materials that is less soluble than $\mathrm{Li}_{2} \mathrm{PdO}_{2}$. Although the leaching rate of Rh significantly increased with increasing $\mathrm{HCl}$ concentration, it did not completely leach, similar to the case of Pd. This was because some $\mathrm{Rh}$ remained unreacted. Although the calcination of $\mathrm{Rh}$ powder and $\mathrm{Li}_{2} \mathrm{CO}_{3}$ generates $\mathrm{LiRhO}_{2}$, some unreacted $\mathrm{Rh}$ remains after calcination at $800{ }^{\circ} \mathrm{C}$ for $3 \mathrm{~h}$ [13]. Since PGMs rarely dissolve in $\mathrm{HCl}$ in the metallic state, the extent of dissolution decreases if unreacted PGMs exist.

The leaching rates of $\mathrm{Li}$ varied between $96.1 \%$ and $98.3 \%$ for the samples using $\mathrm{Li}_{2} \mathrm{CO}_{3}$ and between $46.7 \%$ and $50.7 \%$ for those using $\mathrm{LiF}$ alone, and they were almost constant regardless of the $\mathrm{HCl}$ concentration. Because the calcination products varied depending on the Li salt added, the type of decomposition products is believed to reflect the leaching 
behavior of $\mathrm{Li}$. In other words, $\mathrm{Li}$ was almost completely leached from the products (i.e., from $\mathrm{Li}_{2} \mathrm{O}\left(\mathrm{Al}_{2} \mathrm{O}_{3}\right) \mathrm{SiO}_{2}$ and $\left.\mathrm{Li}_{4} \mathrm{SiO}_{4}\right)$ when $\mathrm{Li}_{2} \mathrm{CO}_{3}$ was used. In contrast, when $\mathrm{LiF}$ was added, $\mathrm{MgF}_{2}$ remained even after $\mathrm{HCl}$ leaching; it was likely that some $\mathrm{Li}$ was also present.

\subsubsection{Calcination Temperature (Conditions I-D-1, I-D-2, I-D-3, and I-D-4)}

Figure 10 shows the leaching rates of the metals from samples obtained by changing the calcination temperature (conditions I-D-1, I-D-2, I-D-3, and I-D-4). Almost complete leaching of PGM and $\mathrm{Li}$ was possible upon calcination between 600 and $900{ }^{\circ} \mathrm{C}$. More specifically, the leaching rates were $89.6-100 \%$ for $\mathrm{Pt}, 79.1-86.5 \%$ for $\mathrm{Rh}, 81.7-85.0 \%$ for $\mathrm{Pd}$, and $97.9 \%$ for $\mathrm{Li}$. For both $\mathrm{Li}$ and $\mathrm{Pd}$, the leaching rates were mostly maintained at these calcination temperatures. In contrast, a maximum difference of $10 \%$ was observed in the leaching rates of Pt. All PGMs showed maximum leaching rates from the samples calcined at $800{ }^{\circ} \mathrm{C}$; the entire amount of $\mathrm{Pt}, 85.0 \%$ of $\mathrm{Rh}$, and $86.5 \%$ of $\mathrm{Pd}$ were leached under this condition.

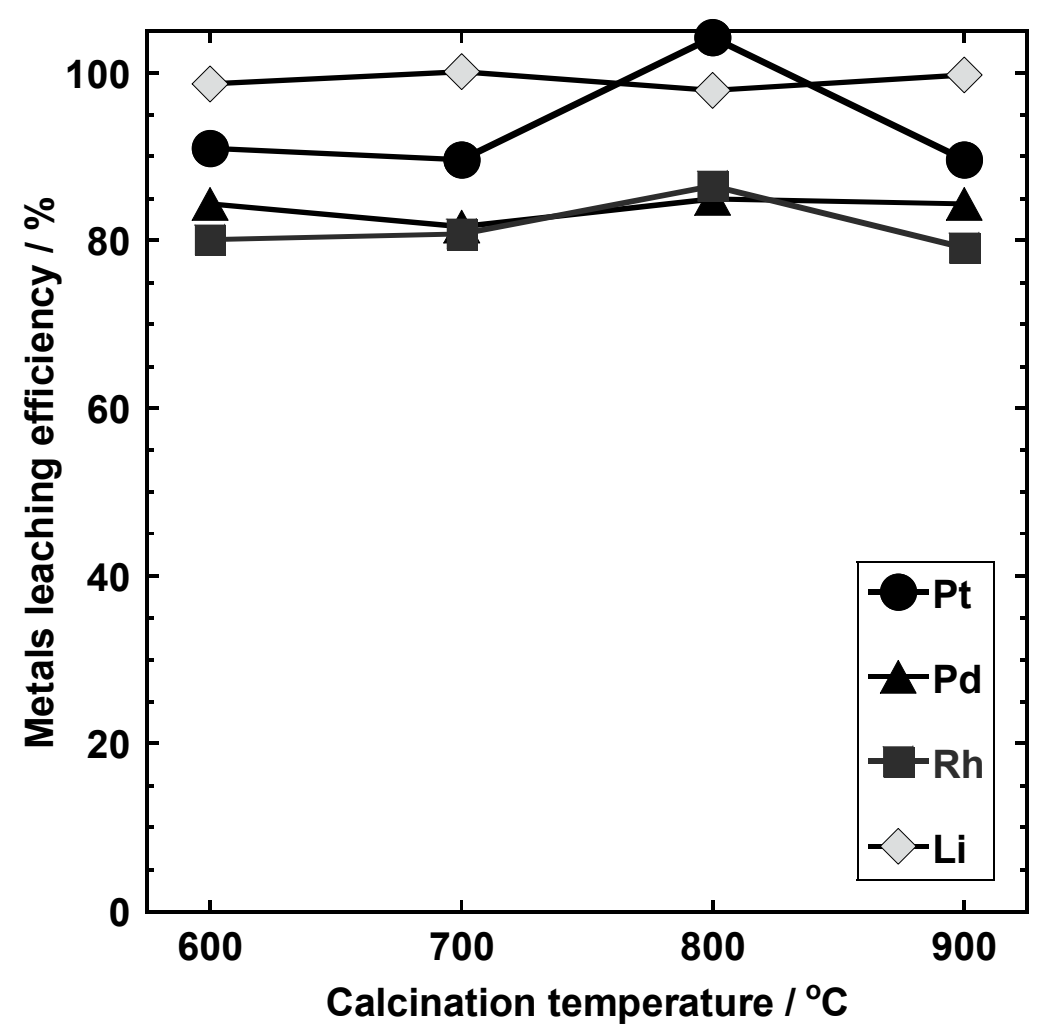

Figure 10. Pt, Pd, Rh, and Li leaching efficiencies of the samples obtained under conditions I-D-1, I-D-2, I-D-3, and I-D-4.

\subsubsection{Calcination Time (Conditions I-E-1, I-E-2, I-E-3, and I-E-4)}

Figure 11 shows the leaching rates of the metals from the samples obtained by varying the calcination time at $800{ }^{\circ} \mathrm{C}$ (conditions I-E-1, I-E-2, I-E-3, and I-E-4). Pt and Li were completed leached after 1,2 , and $3 \mathrm{~h}$ of calcination, while $79.2 \%$ and $82.1 \%$ of $\mathrm{Rh}$ was leached after 0.5 and $1 \mathrm{~h}$, respectively. However, the leaching rate of $\mathrm{Rh}$ reached its maximum, i.e., $94.9 \%$, after $2 \mathrm{~h}$. In addition, the amount of Pd leached after $0.5 \mathrm{~h}$ was $83.7 \%$, and this increased to $94.7 \%$ and $97.5 \%$ after 1 and $2 \mathrm{~h}$, respectively. The reduced leaching rate after $3 \mathrm{~h}$ calcination could be attributed to enhanced sintering and melting. Under the conditions employed in this study, $2 \mathrm{~h}$ of calcination at $800{ }^{\circ} \mathrm{C}$ was concluded to be the optimum condition for the leaching of PGMs. 


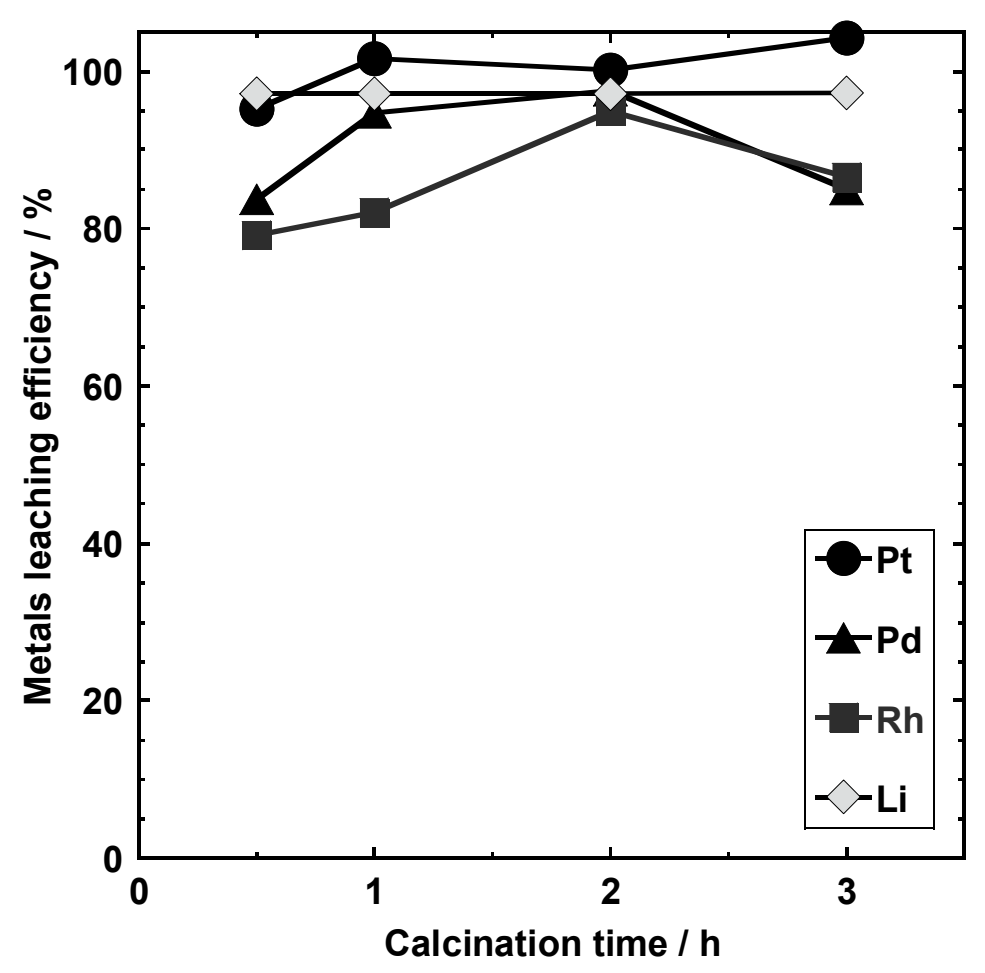

Figure 11. Pt, Pd, Rh, and Li leaching efficiencies of the samples obtained under conditions I-E-1, I-E-2, I-E-3, and I-E-4.

\section{Conclusions}

In this study, the recovery of PGMs from spent automotive catalysts (autocatalysts) was attempted using Li salts and $\mathrm{HCl}$ according to the concept of "spent autocatalyst + waste LIBs $\rightarrow$ resources". As a result, the complete leaching of Pt from samples containing added $\mathrm{Li}_{2} \mathrm{CO}_{3}$ was achieved using $\mathrm{HCl}$. Under the same conditions, the amounts of $\mathrm{Rh}$ and $\mathrm{Pd}$ leached were $94.9 \%$ and $97.5 \%$, respectively. Upon the addition of $\mathrm{LiF}$ to the samples, the amount of leached Pt decreased by approximately $5 \%$, but there was no significant change in the amounts of leached $\mathrm{Rh}$ and $\mathrm{Pd}$. XRD analysis revealed that a complex oxide- $\mathrm{Li}_{4} \mathrm{SiO}_{4}$ - was generated when $\mathrm{Li}_{2} \mathrm{CO}_{3}$ was added to the samples, and that $\mathrm{LiAlSiO}_{4}$ formed when $\mathrm{LiF}$ was added. Therefore, a close relationship was confirmed between the generation of these compounds and the leaching behavior of Li. Furthermore, the immobilization of $\mathrm{F}$ on cordierite, which is a matrix component of the autocatalysts, was observed. $\mathrm{Mg}$ present in cordierite reacted with $\mathrm{F}^{-}$ions in solution to generate $\mathrm{MgF}_{2}$, which plays a significant role in the immobilization of F. Optimal leaching efficiencies were obtained through calcination at $800^{\circ} \mathrm{C}$ for $2 \mathrm{~h}$. The leaching efficiency increased with $\mathrm{HCl}$ concentration and reached the maximum at $12 \mathrm{M} \mathrm{HCl}$.

Author Contributions: Conceptualization, S.K. and R.K.; methodology, S.K. and R.K.; formal analysis, M.O. and R.K.; investigation, M.O.; data curation, S.K. and R.K.; writing - original draft preparation, S.K. and R.K.; writing - review and editing, S.K. and R.K.; visualization, R.K.; funding acquisition, S.K. and R.K. All authors have read and agreed to the published version of the manuscript.

Funding: This research was funded by JSPS KAKENHI, grant numbers 17H01925 and 19K12435.

Institutional Review Board Statement: Not applicable.

Informed Consent Statement: Not applicable.

Data Availability Statement: The data can be provided by the corresponding author on request.

Acknowledgments: The authors would like to express their sincere gratitude to Takumi Akiyama, Masaya Hino, and Erika Furukawa (Tohoku University) who conducted the ICP-MS and ICPAES experiments. 
Conflicts of Interest: The authors declare no conflict of interest.

\section{References}

1. Johnson Matthey Plc. Pgm Market Report. May 2021. Available online: http://www.platinum.matthey.com/documents/newitem/pgm-market-reports/pgm-market-report-may-21.pdf (accessed on 2 July 2021).

2. Johnson Matthey Plc. Platinum 2013 Interim Review. Available online: http:/ /www.platinum.matthey.com/documents/marketreview/2013-interim/full-review/english.pdf (accessed on 2 July 2021).

3. International Energy Agency. Trends in electric mobility. In Global EV Outlook 2020; IEA Publications: Paris, France, 2020; Chapter 1; Volume 2020, pp. 39-85. Available online: https://www.iea.org/reports/globa-ev-outlook-2020 (accessed on 2 July 2021).

4. International Energy Agency. Prospects for Electric Mobility Deployment to 2030. In Global EV Outlook 2020; IEA Publications: Paris, France, 2020; Chapter 3; Volume 2020, pp. 153-184. Available online: https:/ / www.iea.org/reports/global-ev-outlook-2020 (accessed on 2 July 2021).

5. Meeting for the New Era of Automobiles. Available online: https://www.meti.go.jp/committee/kenkyukai/seizou/jidousha_ shinjidai/pdf/001_01_00.pdf (accessed on 19 July 2021).

6. Crundwell, F.; Moats, M.; Ramachandran, V.; Robinson, T.; Davenport, W.G. Refining of the Platinum-Group Metals. In Extractive Metallurgy of Nickel, Cobalt and Platinum Group Metals; Elsevier: Oxford, UK, 2011; Chapter 37; pp. 489-534. [CrossRef]

7. Barnes, J.E.; Edwards, J.D. Solvent Extraction at Inco's Acton Precious Metal Refinery. Chem. Ind. 1982, 6, $151-155$.

8. Kasuya, R.; Miki, T.; Morikawa, H.; Tai, Y. Synthesis of Alkali Metal Platinates and Their Dissolution Behavior in Hydrochloric Acid. J. Ceram. Soc. Jpn. 2013, 121, 884-890. [CrossRef]

9. Kasuya, R.; Miki, T.; Tai, Y. Preparation of $\mathrm{Li}_{2} \mathrm{PtO}_{3}$ and Its Dissolution Properties in Hydrochloric Acid. J. Ceram. Soc. Jpn. 2013, 121, 261-264. [CrossRef]

10. Kasuya, R.; Miki, T.; Morikawa, H.; Tai, Y. Synthesis of Sodium Platinates and Their Dissolution Behaviors in Hydrochloric Acid: Effects of Lithium Carbonate Addition on Platinate Formation. Int. J. Miner. Process. 2014, 128, 33-39. [CrossRef]

11. Kasuya, R.; Miki, T.; Morikawa, H.; Tai, Y. Dissolution Process of Palladium in Hydrochloric Acid: A Route via Alkali Metal Palladates. Metall. Mater. Trans. B 2015, 46, 2476-2483. [CrossRef]

12. Kasuya, R.; Miki, T.; Morikawa, H.; Tai, Y. Dissolution of Platinum in Catalyst Materials Using Hydrochloric Acid: A New Method Based on the Use of Complex Oxides. Miner. Eng. 2016, 87, 25-31. [CrossRef]

13. Kasuya, R.; Nomura, K.; Narita, H. Solubilization of Rhodium in Hydrochloric Acid Using an Alkali Metal Salt Method. Metall. Mater. Trans. B 2020, 51, 377-385. [CrossRef]

14. U. S. Geological Survey. Mineral Commodity Summaries; United States Geological Survey: Reston, VA, USA, 2021; pp. 98-99. [CrossRef]

15. International Energy Agency. The Role of Critical Minerals in Clean Energy Transit. Available online: https://www.iea.org/ reports/the-role-of-critical-minerals-in-clean-energy-transitions (accessed on 19 July 2021).

16. Li, J.; Wang, G.; Xu, Z. Environmentally Friendly Oxygen-Free Roasting/Wet Magnetic Separation Technology for In Situ Recycling Cobalt, Lithium Carbonate and Graphite from Spent $\mathrm{LiCoO}_{2} /$ Graphite Lithium Batteries. J. Hazard. Mater. 2016, 302, 97-104. [CrossRef]

17. Sit, K.; Li, P.K.C.; Ip, C.W.; Li, C.W.; Wan, L.; Lam, Y.F.; Lai, P.Y.; Fan, J.; Magnuson, D. Studies of the Energy and Power of Current Commercial Prismatic and Cylindrical Li-Ion Cells. J. Power Sources 2004, 125, 124-134. [CrossRef]

18. Natarajan, S.; Boricha, A.B.; Bajaj, H.C. Recovery of Value-Added Products from Cathode and Anode Material of Spent LithiumIon Batteries. Waste Manag. 2018, 77, 455-465. [CrossRef]

19. Swain, B. Recovery and Recycling of Lithium: A Review. Sep. Purif. Technol. 2017, 172, 388-403. [CrossRef]

20. Heelan, J.; Gratz, E.; Zheng, Z.; Wang, Q.; Chen, M.; Apelian, D.; Wang, Y. Current and Prospective Li-Ion Battery Recycling and Recovery Processes. JOM 2016, 68, 2632-2638. [CrossRef]

21. Bertuol, D.A.; Machado, C.M.; Silva, M.L.; Calgaro, C.O.; Dotto, G.L.; Tanabe, E.H. Recovery of Cobalt from Spent Lithium-Ion Batteries Using Supercritical Carbon Dioxide Extraction. Waste Manag. 2016, 51, 245-251. [CrossRef]

22. Biswal, B.K.; Jadhav, U.U.; Madhaiyan, M.; Ji, L.; Yang, E.-H.; Cao, B. Biological Leaching and Chemical Precipitation Methods for Recovery of Co and Li from Spent Lithium-Ion Batteries. ACS Sustain. Chem. Eng. 2018, 6, 12343-12352. [CrossRef]

23. da Cunha, J.M.; Klein, L.; Bassaco, M.M.; Tanabe, E.H.; Bertuol, D.A.; Dotto, G.L. Cobalt Recovery from Leached Solutions of Lithium-Ion Batteries Using Waste Materials as Adsorbents. Can. J. Chem. Eng. 2015, 93, 2198-2204. [CrossRef]

24. Kuzuhara, S.; Ota, M.; Tsugita, F.; Kasuya, R. Recovering Lithium from the Cathode Active Material in Lithium-Ion Batteries via Thermal Decomposition. Metals 2020, 10, 433. [CrossRef]

25. Larsson, F.; Andersson, P.; Blomqvist, P.; Mellander, B.E. Toxic Fluoride Gas Emissions from Lithium-Ion Battery Fires. Sci. Rep. 2017, 7, 10018. [CrossRef] [PubMed]

26. Handel, P.; Fauler, G.; Kapper, K.; Schmuck, M.; Stangl, C.; Fischer, R.; Uhlig, F.; Koller, S. Thermal aging of electrolytes used in lithium-ion batteries-An investigation of the impact of protic impurities and different housing materials. J. Power Sources 2014, 267, 255-259. [CrossRef] 
27. Wang, M.; Tan, Q.; Liu, L.; Li, J. A Facile, Environmentally Friendly, and Low-Temperature Approach for Decomposition of Polyvinylidene Fluoride from the Cathode Electrode of Spent Lithium-ion Batteries. ACS Sustain. Chem. Eng. 2019, 7, 12799-12806. [CrossRef]

28. Tanaka, F.; Lkhagvasuren, G.; Terakado, O.; Kuzuhara, S.; Kasuya, R. Dehydrofluorination behavior of poly(vinylidene fluoride) during thermal treatment using calcium carbonate. Metals 2021, 702, 178977. [CrossRef]

29. National Institute of Standards \& Technology. Certificate of Analysis, Standard Reference Material 2557, Used Auto Catalyst (Monolith). Available online: https:/ / www-s.nist.gov/srmors/view_cert.cfm?srm=2557 (accessed on 2 July 2021).

30. Pan, K.; Hu, C.; Sun, Z.; Xu, G.; Zhang, D.; Yu, L.; Wang, K.; Jiang, K. Structural and electrochemical characterization of LiMn ${ }_{2} \mathrm{O}_{4}$ and $\mathrm{Li}_{1.05} \mathrm{Mn}_{1.97} \mathrm{Nb}_{0.03} \mathrm{O}_{4}$ with excellent high-temperature cycling stability synthesized by a simple route. J. Appl. Electrochem. 2020, 50, 451-462. [CrossRef]

31. Musić, S.; Filipović-Vinceković, N.; Sekovanić, L. Precipitation of Amorphous $\mathrm{SiO}_{2}$ Particles and Their Properties. Braz. J. Chem. Eng. 2011, 28, 89-94. [CrossRef] 